\title{
The Creation of Conrail and its Impact on Railroad Regulation
}

\section{By Gregg Guetschow}

Abstract: This article examines the process through which public policy was developed following the bankruptcy of the Penn Central railroad in 1970 to provide for the continuation of rail services in the Northeast and to remedy conditions resulting from federal regulation of the rail industry. The history of rail regulation is described from the perspective of its impact on the operation of the railroads and their financial performance. Four acts -the Regional Rail Reorganization Act of 1973, the Railroad Revitalization Act of 1976, the Staggers Rail Act of 1980, and the Northeast Rail Service Act of 1981-are described in terrns of the policy and political pressures that led to their enactment.

\section{Introduction}

The current environment in the freight rail industry is one characterized by mergers and acquisitions intended to improve operating efficiencies and enhance profitability. The resulting dominance of the market by a few large companies might be expected to result in increased scrutiny by regulatory agencies as has occurred in other industries. A more balanced understanding of the role of the federal government in regulating railroad operations, however, requires familiarity with more than a century of government involvement with the industry. This perspective is helpful in explaining the current public policy environment relative to freight railroads, but is also instructive with regard to the potential impact of government involvement in other sectors of the economy.

The history of the development and operation of railroads in the United States can be characterized by the nature of the relationship between private enterprise

Gregg Guetschow is currently a doctoral candidate in the School of Public Affairs and Administration at Western Michigan University, in Kalamnzoo, Michigan and the city manager of Owosso Michigan. Mr. Guetschow received a B.A. in 1975 and an M.P.A. in 1978 from Western Michigan University. and government. States provided charters to companies seeking to provide rail services and the federal goverrment granted land and powers of eminent domain to enable the laying of rail lines. Initially the states and later the federal government regulated rates for rail services. During World War I the federal government nationalized the railroads, subsequently returning them to private operators. Beginning in the early 1970s, in response to concerns for the viability of railroads generally and in reaction to the bankruptcy of the largest railroads, the policy of the federal government toward railroads shifted.

As an aid to analyzing this development, the stages of the policy process outlined in B. Guy Peters' American Public Policy will be employed. ${ }^{1}$ These stagesagenda setting, policy formulation, legislative legitimation, budgeting, organizational setting, implementation, evaluation, and policy change-provide a framework for understanding the intricacies of policy formulation in general, and, in this case, the formulation of contemporary railroad policy in particular.

\section{History of Federal Regulation}

In fostering the development of the rail industry in the United States, the federal government adopted an attitude that went well beyond laissez-faire and constituted a significant helping hand in the form of land grants and powers of condemnation. These tools were necessary to insure that rail transportation would be available to assist in the opening of the West and the industrialization of the economy. 


\section{POLICY PERSPECTIVES}

Railroading quickly became a lucrative enterprise. Operating free of regulation and, in many cases, as monopolies, railroad owners were able to charge rates sufficient to insure significant return on their investments. This financial performance attracted additional capital in the form of competing railroads. Cartels soon developed within the industry to control rates. However, because these cartels rarely were able to control defectors, rate wars were commonplace. Against this backdrop, and in the absence of federal regulation, several states passed legislation to regulate the rates charged by railroads. ${ }^{2}$ Subsequent to a U.S. Supreme Court decision that found state regulation of railroads to be unconstitutional, the U.S. Congress passed the Interstate Commerce Act in 1887 and set up the first transportation regulatory commission. ${ }^{3}$

In establishing the Interstate Commerce Commission (ICC), the Congress sought to bring order to the rail industry through oversight of rates charged by railroads. The relationship between railroads and the government embodied in the 1887 legislation reflected the perception that railroads had a public character and so should serve the public interest. ${ }^{4}$

The act embodied common law principles applicable to common carriers, requiring rates be reasonable, discrimination against shippers be prohibited, and preferences among areas be banned. ${ }^{5}$ Subsequent amendments, necessitated by gaps in the original legislation, expanded the control of the ICC to include setting maximum and minimum rates, regulating railroad mergers, and controlling the abandonment of rail lines. Further, the ICC was charged with carrying out other national policies through its regulatory actions, such as equalization of port traffic and assistance to agriculture and depressed industries. ${ }^{6}$ The result of this approach to regulation was the establishment, in effect, of a government-sponsored cartel. ${ }^{7}$

\section{Problems in the Rail Industry}

Concerns over the health of the rail industry had surfaced during discussions about the return of the railroads to private operation following World War I. These concerns led to the passage of the Transportation Act of 1920 , which attempted to maintain common carrier service obligations and guarantee adequate rates of return. ${ }^{8}$ The act permitted the ICC to set minimum rates, transferred entry into and exit from routes from the states to the ICC, granted the ICC the right to promote mergers of railroads as a means of rationalizing service, and provided guaranteed loans for weaker railroads.

Problems in the rail industry became particularly pronounced beginning in the 1950s. The Transportation Act of 1958 offered some relief by allowing railroads more flexibility in reducing rates and abandoning unprofitable passenger services. ${ }^{9}$

Factors negatively affecting the financial strength of the railroads were evident nationally but their effects were more pronounced in the Northeast. ${ }^{10}$ Competition had expanded in the trucking, barge, and airline industries as a benefit from federal investment in interstate highways, waterways, and airports. The ICC regulated the majority of railroad charges, but a smaller portion of the charges of the trucking and barge industries. This left railroads at a competitive disadvantage to competing forms of carriage. Expanded automobile use deprived trains of significant passenger volumes. Furthermore, heavy industry had begun migrating from the Northeast to the South and West; the industry that remained was shifting from use of train-delivered coal for power needs at individual plants to the purchase of power from private utilities.

The labor environment under which railroads operated also contributed to their poor financial performance. Work rules affecting train crews resulted in inefficient staffing and a lack of productivity in yard operations. 


\section{THE CREATION OF CONRAIL}

As a former Department of Transportation (DOT) secretary explained, "This union structure evolved during the late 1800 's and largely predated any of this country's labor laws. The Railway Labor Act (RLA) of 1926 was designed to accommodate and preserve the institutional structure in existence at that time." ${ }^{\prime 11}$

The effect of this change on the rail industry was a reduction in profitability. The ICC noted a rate of return on net worth for the entire industry in 1969 of just one percent, as compared to 14.9 percent for common carrier trucking. ${ }^{12}$ The industry responded by merging railroads, seeking to abandon unprofitable lines, and by postponing capital investment. However, the ICC was slow in granting merger requests; many required a period of several years before final approval. Those that were approved reflected an ICC bias in favor of parallel mergers intended to eliminate duplicate lines, even though studies had questioned the advisability of such mergers ${ }^{13}$ and had further suggested that there were diseconomies of scale in the merging of large railroads. ${ }^{14}$

The ICC responded to political pressure to require service be maintained on branch lines. In concluding that the public interest was reflected in the availability of rail services, it typically required the continuation of unprofitable lines. ${ }^{15}$ The least used, and consequently less profitable, branch lines tended to be approved for abandonment more quickly than more heavily used and more profitable lines. ${ }^{16}$ Shippers sought to maintain branch lines as a tool to maintain competition for trucking firms even if they were not using those lines. ${ }^{17}$ The ICC expected that unprofitable branch lines would be subsidized by profitable main lines, just as it required that unprofitable passenger service be subsidized by profitable freight service. ${ }^{18}$

The squeeze on profitability left railroads with little capital available to invest in repairing aging track. As a result, trains were forced to operate at slower than op- timum speeds in order to avoid derailments. The rates charged for freight encouraged assembling longer trains, which necessitated keeping cars in rail yards for extended periods. Further, the need to insure compatible hardware across the industry so that cars could be shared among railroads limited the ability to modernize equipment. These and other factors related to the very nature of the industry resulted in slow product delivery; those products that were shipped tended to be low in value relative to weight since these benefited from lower rates. The more highly valued but lighter products were uneconomical to ship by rail not only because of the rate structure ${ }^{19}$ but also because they suffered more damage due to the way in which trains were assembled from individual cars. ${ }^{20}$

\section{The Penn Central Crisis}

While the Penn Central would be neither the first railroad to enter bankruptcy nor the last, its size made it the most spectacular. It was formed on February 1, 1968, out of a merger of the Pennsylvania Railroad and the New York Central Railroad, and was, at the time, the largest corporate merger in U.S. history. When the merger was originally proposed in 1957, it was claimed that the Penn Central would "serve 13 states, employ one of every six American rail workers, own one-sixth of the nation's locomotives, one-third of its passenger coaches and onesixth of its freight cars. ${ }^{\prime 21}$ On the eve of the merger, it was projected that the Penn Central would serve over half of the country's manufacturing plants and fifty military facilities. ${ }^{22}$ On June 21, 1970, it became the largest bankruptcy in history.

Individually, the Pennsylvania and the New York lines had been profitable enterprises but only because losses in rail operations had been offset by profits in other areas such as real estate. The two railroads had operated as competitors in the Northeast along parallel lines. In 
seeking approval for the merger, the ICC required that the deal include acceptance of the New Haven line that had been in bankruptcy since 1961 and "was in wretched physical condition." ${ }^{23}$ Acquiescence by 23 affected unions had been achieved by negotiating lucrative income protection guarantees for all workers on the merged line. ${ }^{24}$

Poor management contributed to a failure to realize much of the promised benefits from the merger. While these factors alone did not cause the bankruptcy, they accelerated the pace at which other factors affecting the industry generally would undermine the ability of the railroad to operate profitably. The Penn Central lost nearly $\$ 83$ million in 1969 and four times that amount in $1970 .{ }^{25}$

Bankruptcy proceedings enabled the continued operation of the Penn Central pending a plan for its reorganization. Congress relieved the Penn Central and most other railroads of intercity passenger service when it created the National Rail Passenger Corporation (Amtrak) with passage of the Rail Passenger Service Act of 1970. While policy makers might have believed that this action would resolve the financial problems facing railroads, unprofitable operations continued. ${ }^{26}$ The demands on the enterprise's cash reserves were such that the trustees operating the railroad were faced with a decision to cease business. ANixon administration offer of $\$ 200$ million in emergency loan guarantees was withdrawn after it became known that one of the Penn Central's law firms had previously employed Nixon and Attorney General Mitchell. Likewise, Congress blocked a DOT offer of $\$ 150$ million in guarantees.

Ultimately, however, the prospects of stranding nearly a quarter of a million commuters and causing severe impacts on the economy led Congress, at the end of 1970 , to authorize emergency legislation guaranteeing loans to the Penn Central. ${ }^{27}$ This action would later be described as the beginning of a radical change from practices in effect since returning the railroads to private op- eration at the end of World War I, a change characterized by longer schedules for repayment of loans, interest rates which were lower than the federal government's cost of borrowing, and grants to private companies. ${ }^{28}$

\section{Agenda Setting}

Peters notes a number of factors which are important in moving a problem onto the institutional agenda so that Congress may consider action. ${ }^{29}$ Those factors relevant to the case of the Northeast rail crisis included the visibility of the problem, a concentration of victims in a particular region, the absence of private means, and, particularly with regard to the demand for deregulation, the spillover effect of other government programs related to transportation.

Problems in the rail industry were not news to the Congress. Hearings had been held as early as $1958 .^{30}$ While various committees held hearings on aspects of the Penn Central crisis, these tended to focus on corporate mismanagement rather than on problems within the rail industry as a whole. ${ }^{31}$ In testimony before the Senate Surface Transportation subcommittee, there was a lack of unanimity regarding the cause of the present crisis or its ultimate solution. ${ }^{32}$ The issue of nationalizing the railroads had been raised in comments on the Senate floor, but no serious effort was being made to advance legislative proposals. ${ }^{33}$

Further, bankruptcy of a railroad generally had not been a reason for congressional action. The provisions of the bankruptcy code favored reorganization or acquisition by another railroad, subject to ICC approval. The ability to restructure debt could enable a continuation of operations.

This was not to be the case with the Penn Central, however. The size of the enterprise alone made it impossible to find a takeover candidate. Wilner (1997) states that the company was too large to be taken over by any 


\section{THE CREATION OF CONRAIL}

entity other than the federal government. ${ }^{34}$ After failing to find prospects for a takeover of operations, the bankruptcy court began to entertain proposals for liquidation of assets in order to satisfy creditors, an action that would have resulted in the end of rail service in much of the Northeast. $^{35}$

The Penn Central was not the only railroad operating in the Northeast to enter bankruptcy. The New Haven and Jersey Central had been bankrupt since 1961 and 1967 respectively; the Lehigh Valley also declared bankruptcy in 1970, followed by the Reading in 1971, and the Erie Lackawanna and Lehigh and Hudson River railroads in $1972 .^{36}$ These railroads represented over 50 percent of the trackage in the region, ${ }^{37}$ which came to be characterized as a "railroad graveyard." ${ }^{38}$

The Penn Central trustees undertook two strategies that were to move this matter onto the institutional agenda. First, they proposed to cease operations on a significant portion of the unprofitable branch lines. The trustees had determined that approximately half the railroad's mileage was no longer profitable to operate; a significant portion of this was proposed for immediate abandonment. ${ }^{39}$ Saunders observes that "lines do not become losers overnight. So the abandonment scheme had a contrived quality...a gimmick to precipitate a crisis. ${ }^{\prime 40}$ As expected, this announcement resulted in expressions of opposition from affected shippers, customers, and communities.

Second, even though the unions had indicated that they would consider addressing the problem of archaic work rules, the trustees unilaterally modified these rules. ${ }^{41}$ As expected, the United Transportation Union struck the railroad, shutting down its operations.

It was not uncommon for Congress to intervene in resolving strikes against railroads. The need to assure continued service to passengers and shippers of the affected line would certainly warrant this action. In addi- tion, actions affecting one railroad tended to affect others due to interline traffic and car supply. ${ }^{42}$ On February 9, 1973, President Nixon signed a joint resolution ordering an end to the strike and prohibiting changes in crew size, lock-outs, or resumption of the strike for 90 days. ${ }^{43}$ The DOT secretary was directed to submit a report to Congress within 45 days detailing a plan for preserving Northeast rail services.

The legislation resulting from this initiative, the Regional Rail Reorganization Act of 1973 (3R Act), would address the problem of the Penn Central and the other bankrupt Northeastern railroads. It did not, however, reflect a larger concern on the part of Congress with factors in the rail industry generally that contributed to weaknesses in the industry. Nonetheless, it created a mechanism for exploring the underlying causes of that weakness. Further, bankruptcies in the railroad industry outside the Northeast, such as the Rock Island and the Milwaukee lines, heightened awareness that there was a larger problem requiring attention. That problem related to the nature of economic regulation affecting the rail industry.

In January 1974, shortly after the approval of the 3R Act, the DOT assisted Congress in drafting the Transportation Improvement Act. This act sought to reform ICC regulation of railroads. ${ }^{44}$

Gerald Ford had voted against the 3R Act while serving in the House of Representatives. As President, he brought to the administration an agenda that included reducing the burden of federal economic regulation which he felt was unnecessary and contrary to the public interest. ${ }^{45}$ The studies required by the $3 R$ Act provided a vehicle through which to influence the direction of future policy development. This direction would be oriented toward addressing the specific problems resulting from the manner in which the ICC regulated the railroad industry. By coupling deregulation with measures 
necessary to implement fully the provisions of the $3 R$ Act, the administration was able to force this issue onto the institutional agenda. The result was the Railroad Revitalization and Regulatory Reform Act of 1976 (4R Act).

\section{Policy Formulation}

The passage of the joint resolution ending the strike against the Penn Central led to a flurry of legislative proposals from Congress. These included nationalization of the rail industry and acquisition of rail lines with improvements financed by user fees charged to railroads. The Nixon administration circulated a proposal to establish a corporation with broad powers to sharply reduce rail services and decrease the ICC's role in reorganization and regulation. The ICC, on the other hand, sought to offer government loans financed by a freight tax together with new authority for the Commission over service reductions. ${ }^{46}$

Creative policy formulation often results from an environment characterized by a lack of information about a problem and the absence of a theory of causation. ${ }^{47}$ Despite the significant effects of the rail problems throughout the Northeast, no clear consensus had been achieved about their causes, nor was it known that these problems were industry-wide in scope, unrelated to the management of particular railroads. That this environment would yield the legislative solutions that it did, particularly when developed principally by interest groups, seems consistent with Peters.

\section{The Regional Rail Reorganization Act of 1973}

The Union Pacific railroad viewed the various legislative proposals skeptically and was concerned that the failure to arrive at a reasonable legislative solution would result in liquidation of the Penn Central. This outcome would have been detrimental to its in- terests in that 25 percent of its business originated or terminated in the Northeast. ${ }^{48}$ As a consequence, it sought to craft a legislative solution that would address the Penn Central crisis. The chief counsel of the Union Pacific was the principal author of the legislation. ${ }^{49}$

This legislation, which was to become the 3R Act, provided for the creation of the United States Railway Association (USRA), a non-profit corporation which would issue federally-guaranteed loans for the operation of the railroads and for replacement of deteriorated rail lines. The USRA would be governed by a board composed of representatives from the rail industry, federal, state, and local governments, unions, shipper organizations, and financial interests. The offbudget nature of these loans was important in addressing Nixon administration concerns about capping budget increases. ${ }^{50}$ In addition, the USRA would be charged with studying the problem of rail service in the Northeast and drafting a plan for addressing the problem.

A for-profit enterprise was also created by the legislation, the Consolidated Rail Corporation (Conrail). This corporation would have the responsibility for operating the rail system devised by the USRA.

The 3R Act required reports from the DOT regarding its recommendations for resolving the Northeast rail problem and also established a new agency within the ICC, the Rail Services Planning Office, that would have the responsibility of reviewing and commenting upon the recommendations from the USRA.

A potential outcome of the $3 R$ Act's passage would be the consolidation of operations resulting in the loss of jobs provided by the Penn Central. To insure union support for the legislation, income protection guarantees were included in the bill, at a cost of $\$ 250 \mathrm{mil}$ lion. 
THE CREATION OF CONRAIL

\section{The Railroad Revitalization and}

\section{Regulatory Reform Act of 1976}

The $4 R$ Act was necessary to implement the recommendations from the USRA regarding rail service in the Northeast, but it also incorporated provisions necessary to address the problems in rail service nationwide. However, the administration's hopes were focused on the bill's regulatory reform provisions. In an effort to restrict the ICC's influence on factors affecting the profitability of railroads, the ICC was required to find market dominance before continuing rate regulation for a railroad. Further, the process of abandonment was to be modified so as to speed up the elimination of unprofitable lines.

\section{Legislative Legitimation}

The 3R Act Albright observes that "it is no wonder that the legislative history of the Northeast railroad bill is confusing, in that it was designed and pushed through Congress by officers of special-interest groups that stand to benefit from its provisions. ${ }^{151}$

The Union Pacific legislation was introduced in the House under the sponsorship of Republican Richard Shoup of Montana and Democrat Brock Adams of Washington, the latter of whom had originally declined to do so. Critical to the effort to secure passage was delaying consideration of a bill introduced by Senator Vance Hartke that had been approved by the Surface Transportation Subcommittee of which he was chairman. This bill would have had the federal government take ownership of the rail beds and tracks and finance improvements through user fees charged to railroads. Weyerhaeuser Corporation, a railroad shipper, had operations in the home state of Commerce Committee chairman Warren Magnuson. A lobbyist representing various shippers secured contacts from Weyerhaeuser convincing Magnuson to delay further action on the Hartke bill while the $3 R$ Act was under consideration in the
House. ${ }^{52}$ The financial assumptions related to the 3R Act were provided by First National City Bank. This company stood to have a $\$ 300$ million loan to Penn Central repaid because of the bill. ${ }^{53}$

The $\$ 250$ million cost associated with labor provisions proved a somewhat more difficult issue with regard to passage of the legislation. The future of the railroad as a government enterprise was unknown as the legislation was being debated. Consequently, assumption by the federal government of the labor costs associated with that railroad seemed a questionable policy choice. Nonetheless, the bill was approved. Saunders has noted :

As major bills go, Congress did not put a lot of work into this one. Union Pacific supplied the bill. First National City Bank supplied the financial data. The United Transportation Union supplied the labor contracts. Committee work was minimal. So was floor debate. Support from the South and West was whipped into line with a tart reminder that $\underline{x}$ thousands of freight cars a day rolled into the Northeast with products from other regions. A largely disinterested House passed the bill in November 1973. There was some wrangling in the conference committee, but a largely disinterested Senate, already melting away for the Christmas holiday, passed it in December. The administration put on a blustery show of defiance, claiming it was too costly a burden on the taxpayer (which it wasn't - banks were going to supply most of the capital), but Nixon signed it early in January. Such was the Regional Rail Reorganization Act of $1973 .^{54}$

The 4R Act Richard Shoup and Brock Adams were already celebrated by the rail industry for their role in passing the $3 R$ Act. They would also sponsor the 4R Act in 1976.

For the most part, the act reflected the outcomes of the Final System Plan developed by the USRA pursuant to the $3 \mathrm{R}$ Act. Accordingly, the act included the funds estimated to be required to provide the assistance which Conrail and other railroads would need for operations and capital investments.

Perhaps largely because this act was seen as a continuation of the earlier legislative effort, passage of 
this legislation appears to have generated little more congressional interest than the 3R Act.

\section{Budgeting}

The 3R Act The 3R Act was specifically designed to avoid a problem with the Nixon administration regarding the impact on the budget. It is for that reason that the funds made available for the rehabilitation of railroads were provided through government guaranteed loans. This funding was "off-budget," analogous to debt issued through Fannie Mae. It would not be subject to the national debt ceiling and, therefore, was beyond the reach of the Office of Management and Budget in exercising its veto over the spending. ${ }^{55}$

The 3R Act authorized the USRA to issue debt up to $\$ 1.5$ billion, $\$ 1$ billion of which was designated for Conrail. At least half of this latter amount was to be used for plant modernization. Five hundred million dollars was slated for upgrade of the Boston-Washington route that was to be sold or leased to Amtrak. ${ }^{56}$

The $4 R$ Act The $4 \mathrm{R}$ Act provided $\$ 500$ million over four years as subsidies for branch lines; $\$ 600$ million in grants and $\$ 1$ billion in guaranteed loans to weak railroads; $\$ 1.75$ billion to upgrade Amtrak's BostonWashington route; and $\$ 2.1$ billion in subsidies for Conrail..$^{57}$ This latter amount was determined to be necessary, according to USRA forecasts, to cover operating losses until Conrail could be returned to profitability. However, it was believed that if USRA's projections were off by just three-quarters of one percent, Conrail would have a net deficit of $\$ 368$ million instead of the projected operating income of $\$ 1.699$ billion. $^{58}$

Subsequent Budget Actions The budgetary process would prove more significant in later years. Only the USRA believed its forecasts for Conrail's return to profitability. Despite improvements in service and greater freedom with regard to abandonment of un- profitable lines, the operation continued to lose money. Congress authorized an additional $\$ 1.2$ billion in funding in 1978. By the end of his term of office, President Carter signaled an end to funding for Conrail.

President Reagan would go even further by suggesting that Conrail be broken up and sold off piecemeal to other railroads. The impact of these positions will be discussed in greater detail below.

\section{Implementation}

The 3R Act The 3R Act required DOT to provide recommendations regarding the Northeast rail problem to Congress within a short time following approval of the legislation. However, this study would prove disappointing as DOT failed to offer creative solutions to the problem.

The USRA was given 300 days within which to study the issue and provide recommendations. It would ultimately require considerably more time than this to analyze the problem. The alternatives considered included creating Conrail from the systems of all bankrupt railroads, organizing the railroads into two competing systems, and transferring the lines to other solvent carriers. ${ }^{59}$

Its preferred solution called for portions of the Northeast services to be taken over by two profitable railroads, the Chessie system and Norfolk \& Western. Some lines were slated for abandonment. Conrail would operate the remainder of the Northeast rail system until it returned to profitability. This approach was preferred as a means of meeting the statutory objective of providing for competition in the provision of rail services. ${ }^{60}$ The Chessie and Norfolk \& Western systems insisted that transferred employees come under their labor agreements. That condition was unacceptable to the Penn Central unions and ended consideration of that alternative. ${ }^{61}$ 


\section{THE CREATION OF CONRAIL}

The final recommendation of the USRA, then, called for abandonment of a portion of the system and for Conrail to assume responsibility for operating the balance. As expected, shippers and communities affected by the abandonments expressed opposition to the plan and representatives and senators from affected areas joined them. However, the $3 R$ Act had provided that the "Final System Plan was to have the force of law if it was not disapproved by either house of Congress within sixty legislative days after its release. ${ }^{\prime 62}$ No action was forthcoming and the plan went into effect on November 9, 1975.

This was not the only opposition encountered in implementing the $3 \mathrm{R}$ Act, however. A lawsuit was filed challenging the constitutionality of the law. The U.S. Supreme Court ruled that the law was constitutional. ${ }^{63}$

Further, the ICC did not favor the USRA plan. The Rail Services Planning Office created by the 3R Act was charged with reviewing the USRA recommendations and providing a report to Congress concerning its implementation. The ICC preferred a much different alternative in the form of a one percent tax on rail shipments that would be used to repair aging track. ${ }^{64}$

The real challenge in implementing the $3 R$ Act was in the transfer of responsibilities from the Penn Central to Conrail. This proceeded well. Shippers and customers noticed actual improvements in service quality and few disruptions.

The $4 R$ Act Implementation of the regulatory reform provisions of the $4 R$ Act did not occur as planned. The ICC proved to be reluctant to modify its procedures in order to accomplish the law's provisions.

DOT Secretary Brock Adams reported to Congress regarding the reluctance of the ICC to carry out the intent of the $4 \mathrm{R}$ Act:
One of the DOT's particular concerns is the ICC's interpretation of the provisions of the $4 R$ Act by which the Congress clearly intended to permit rate flexibility to railroads, except in cases where a railroad posesses market dominance. The ICC, however, consistently has interpreted this provision in such a manner as to frustrate the congressional mandate for rate flexibility. The ICC's regulations tend to result in findings of market dominance because they neglect actual competition from other modes, if it cannot be measured adequately, and they ignore potential competition completely. ${ }^{65}$

This report, required by the $4 \mathrm{R}$ Act, helped to set the stage for further legislative actions necessary to more fully implement congressional intent with regard to the deregulation of the railroad industry.

\section{Organizational Setting}

Peters describes various barriers to implementation related to the organizational context of the policy process. Several of these barriers are relevant to understanding the resolution of the Northeast rail crisis including the ICC's standard operating procedures, time problems, and interorganizational politics. ${ }^{66}$

The Department of Transportation had been created in 1967, consolidating transportation-related programs from other federal agencies. The Interstate Commerce Commission was not included among those programs, however, and continued as an independent regulatory commission whose members were appointed by the President. In adopting the $3 R$ Act, Congress added to the bureaucracy surrounding rail issues a non-profit corporation, the USRA, which was independent of the other two, albeit with a limited scope of responsibilities. In addition, the Rail Services Planning Office was added to the ICC and charged with reviewing and commenting upon the USRA's recommendations.

The involvement of the DOT, the ICC and the USRA in the Northeast rail problem created a tension that 


\section{POLICY PERSPECTIVES}

would prove to be as significant to the future of rail policy as the resolution of the Penn Central crisis. From the beginning, the ICC was defensive regarding the role of rate and abandonment regulation in the problems facing the rail industry. At the same time, the DOT perceived an opportunity to expand its sphere of influence, at one point seeking to absorb the role performed by the USRA. ${ }^{67}$

Further, at least some legislators had come to perceive that the ICC had failed to act appropriately in preventing the problems within the rail industry. A bill had been introduced in the Senate to eliminate the ICC and replace it with another commission that would regulate rates. Senator Hartke noted that until reinstituted by him, his subcommittee had not held oversight hearings for 14 years. ${ }^{68}$

This tension became most apparent following the passage of the $4 \mathrm{R}$ Act. In his report to Congress, Brock Adams, who had moved from Congress to DOT Secretary in the Carter Administration, was extremely critical of the obstructionist position taken by the ICC in implementing the regulatory reforms that had been the intent of the legislation. The ICC had been sued to enforce the provisions of the $4 R$ Act dealing with market dominance; however, the U.S. Court of Appeals for the District of Columbia had found in favor of the ICC. With regard to abandonments, however, U.S. Court of Appeals for the Seventh Circuit ruled against the ICC and actions from that point had been more favorably disposed toward implementing the intent of the act.

Some improvement was achieved during Jimmy Carter's presidency. The new ICC chairman had begun to reform the commission in 1977 and 1978. In addition, Carter had appointed two pro-deregulation economists to the commission. However, it was widely believed that legislation more favorable to deregulation would be required. ${ }^{69}$

\section{Evaluation}

The 3R Act was, to some extent, an evaluation mechanism relative to the resolution of the Northeast rail crisis. By establishing a three-way competition among the DOT, USRA and the ICC, the Act assured a series of reports and commentaries regarding the recommendations for resolving the crisis. Ultimately, however, this would prove to be of value only to the extent to which the agencies responded to one another since Congress was limited to a 60-day period within which to consider the recommendation for reorganization.

The USRA, acting as federal banker for Conrail by purchasing its securities, ${ }^{70}$ had the responsibility for monitoring Conrail's performance. While the Ford administration had not achieved all of its regulatory reform goals in the 4R Act, its initial appraisal of the legislation was generally positive. Administration officials commented that "the $4 \mathrm{R}$ Act does provide significant regulatory reform, more than anyone thought we could achieve. The reforms in the bill represent a definite break with the past and provide a good deal of pricing flexibility and reform of archaic ICC procedures. ${ }^{\prime 71}$ The $4 R$ Act similarly required reports to Congress regarding its implementation.

In general, the attempt to improve the railroad's financial situation was seen as unsuccessful, which had led to the conclusion that efforts to effect that change by working through the ICC were not likely to achieve the results which had been anticipated. ${ }^{72}$ The General Accounting Office (GAO), which had responsibility for auditing Conrail's performance, stated "Conrail assumed in its plans that regulatory reform would enable it to make pricing and plant rationalization changes that would produce revenues it could use to rejuvenate its capital programs. Regulatory reform may not allow the freedoms Conrail anticipated. ${ }^{\prime \prime 73}$ 
THE CREATION OF CONRAIL.

\section{Changes in Policy}

The Staggers Rail Act of 1980 The Carter administration had been successful in accomplishing much of what it sought in the deregulation of transportation industries. Airlines and trucking had been the subjects of earlier initiatives. The efforts to foster deregulation through the $4 \mathrm{R}$ Act during the Ford administration had borne little fruit, however, and was to be the focus of attention for policy change regarding this area. Further, the rail industry itself was seeking deregulation, not only in reaction to the need to respond to trucking and barge services, but also because unregulated short-line railroads were proving to be effective competition as well. ${ }^{74}$

The Railroad Deregulation Act of 1979 had been introduced in the Senate and reflected Carter administration interest in a major restructuring of the regulatory framework affecting railroads. ${ }^{75}$ This interest was further piqued by the ICC's recalcitrance in carrying out the intent of the $4 \mathrm{R}$ Act.

The ICC was defensive of its role in implementing regulatory reform, particularly with regard to the issue of abandonments, an area in which it reported improvements. Those improvements were an outcome of a court decision adverse to the ICC with regard to its interpretation of the requirements of the $4 \mathrm{R}$ Act concerning abandonments. The ICC noted that "Conrail has made a highly publicized management decision not to take any actions toward rationalizing its plant before the Congress acts on rail deregulation. ${ }^{n 76}$

Working with House counsel, Representative James Florio drafted a bill that would allow for railroads to automatically adjust the rates that they charge to haul products. ${ }^{77}$. While the amount of rate adjustment in any year was limited, and there were protections for captive shippers, the net effect of the bill was to deregulate railroads with regard to most rate setting.
Representative Florio experienced some difficulty in moving this bill through the House, however. Even though Conrail continued to experience operating deficits, the bill was stalled, perhaps as a result of concerns from shippers that deregulation would result in rate increases. ${ }^{78}$ Deregulation had been defeated on the House floor the first time it had come up for a vote. ${ }^{74}$ Eventually, Florio elected to withdraw the bill. He then sought the support of veteran Representative Harley Staggers, chairman of the Interstate and Foreign Commerce Committee. Staggers had powerful influence in matters dealing with railroads as attested by Amtrak's establishment of service between Washington and his rural West Virginia district. Leaders of railroad unions saw Staggers as a supporter of their interests. By agreeing to name the bill after Staggers, Florio was able to enlist the support necessary to secure passage of the legislation. ${ }^{80}$

The Northeast Rail Seroice Act of 1981 The Staggers Rail Act of 1980 did not address all of the problems facing Conrail in returning to profitability. The labor income protection provisions of the $3 R$ Act had been projected to cost $\$ 250$ million to meet obligations which, at the outside, were expected to last until the year 2021. However, some 13,000 workers each month were drawing a monthly displacement allowance, claiming an average of $\$ 400$ each. This and other benefits resulted in the original allocation being exhausted after only four years. ${ }^{\text {BI }}$ Congress had authorized an additional $\$ 230$ million to address the worker protection provisions of the $3 R$ Act and required Conrail to absorb any costs above this amount. ${ }^{\mathrm{B} 2}$ While Conrail had achieved some success in labor relations, it was facing difficult negotiations. Further, the funds that Congress had approved to finance worker protection provisions in the 3R Act were nearly depleted. In addition, commuter services continued to be subsidized by freight operations. At the end of 1979, accounts payable to Conrail by commuter authorities totaled nearly $\$$ sin million. ${ }^{k+7}$ 
President Carter clearly indicated his intent that no further federal funds be allocated to Conrail. President Reagan went even further, advocating that the railroad be liquidated. ${ }^{84}$ Nonetheless, Conrail faced problems with its unions. While interested in preserving the railroad, they had balked at concessions desired by Conrail that would have set their wages below those of the remainder of the industry. Staff in the House warned the unions that they could only hope to preserve Conrail and their jobs by building political support in the House through acceptance of Conrail's conditions. ${ }^{85}$

The Northeast Rail Service Act of 1981 was introduced by Representative Florio, and set 1994 as the date for transferring Conrail to private ownership. ${ }^{86}$ The act capped the payments to be received by employees under the 3R Act's income protection provisions. The Northeast Rail Service Act also freed Conrail from its obligations to provide money-losing commuter services.

Subsequent Actions Following passage of the 1981 Act, Conrail did become profitable. It was returned to private operations through the sale of its stock, a move that, together with cash returned to the U.S. treasury, yielded $\$ 1.9$ billion for the government. ${ }^{87}$

Of perhaps even greater significance from a public policy standpoint was the elimination of the Interstate Commerce Commission effective December 31, 1995. The functions previously performed by the ICC were transferred to the Surface Transportation Board (STB), an agency under the Department of Transportation. While the ST'B retains many of the ICC's functions and much of its independence, its authority must be periodically renewed by Congress. ${ }^{88}$

\section{Analysis and Conclusions}

Peters notes that "even conservatives who tend to oppose government intervention in the economy appear happy to assist failing industries when it is clear that there will be major regional effects." ${ }^{89}$ It might be difficult to find politicians involved in the Northeast rail crisis who would be characterized as happy, whether conservative or liberal. It is noteworthy, nonetheless, that there seemed little debate over whether the government should become involved in resolving the problem, only how. The Regional Rail Reorganization Act of 1973 was passed with relative ease. There appears to have been little consideration given to philosophical positions concerning whether or not government involvement was appropriate. It is difficult to reach any conclusion other than that the history of prior involvement in the rail industry inclined policy makers toward an effort at rescue.

Perritt suggests that more could have been achieved in addressing the problem of the Northeast railroads:

In enacting the 1973 [3R] Act, Congress created a statutory mechanism under which industry structure problems could be addressed more freely than under the Interstate Commerce Act or section 77 of the Bankruptcy Act. Unfortunately, the USRA did not take advantage of this opportunity. ${ }^{90}$

This passage highlights well the incremental nature of the process of developing public policy in this area. ${ }^{91}$ Congress faced an enormous problem and responded with partial, though temporary, nationalization of a significant portion of the rail industry, a somewhat radical solution. It is tempting to view this resolution of the Northeast rail crisis as a major policy shift from the past. I would argue that such a view is only possible by compressing the impact of nearly a century of government regulatory control of the rail industry into the decade following the Penn Central bankruptcy.

A review of the history of railroads since the passage of the Interstate Commerce Act of 1887 permits a perspective in which each federal policy development, including the legislation adopted since 1970, can be 


\section{THE CREATION OF CONRAIL}

seen as building on that which preceded it. That history, dictated by the protection of public interest in a viable and affordable rail service, saw the creation of the first independent regulatory commission and its being accorded significant powers to control the rail industry. Subsequent legislation granting only partial regulation of competing forms of carriage and subsidizing that competition through public investment in infrastructure led to the financial crisis characterized by a wave of railroad bankruptcies.

The creation of Amtrak in 1970 might easily be seen as a revolutionary outcome of this crisis. However, it was not the first of the government-sponsored enterprises. It must be considered in light of the nationalization of railroads during World War I and the subsidy of passenger and commuter service that had existed prior to 1970. The establishment of Amtrak then seems a logical successor policy responsive to an interest in aiding railroads and in ensuring the continuation of the service.

Once Amtrak was created, it was not difficult to conceive of a similar corporation to assume the responsibility for Northeast freight operations, particularly when no other viable options were presented for preserving the service through private operators.

The deregulation of railroads is best understood as a series of incremental changes more similar to the winding down of a process that was wound up beginning in 1887. Transportation deregulation had begun in other competing industries that had been only partially regulated. The first attempt at rail deregulation had focused on redefining the conditions under which regulation could continue; the power remained with the ICC. The Staggers Rail Act contemplated a gradual adjustment of rates rather than a wholesale shift.

Finally, this policy process set the stage for elimination of the ICC and thus might be perceived as a more comprehensive policy solution. However, Huntington noted the conditions influencing the longevity of this agency long before the Northeast rail problems led to a questioning of the need for the ICC. ${ }^{92}$ In the 1950's, the ICC was being challenged by the newly created Office of the Undersecretary of Commerce for Transportation. ${ }^{93}$ The alienation of other agencies, a result of the ICC's narrow interests, was but one problem identified as challenges to the agency's survival. Others included the loss of support from non-rail interest groups and the subversion of congressional intent relative to fair and impartial regulation of transportation. ${ }^{94}$

The creation of the Department of Transportation, by assembling transportation-related programs from other agencies, clearly contributed to the further decline of the ICC. There now existed an agency with broad powers in virtually every area except railroad regulation. Furthermore, ICC elimination can be seen to be a much less significant policy decision when one considers that its successor, the Surface Transportation Board, exercises much the same powers in much the same way, except with a more systematic process of congressional oversight.

If an issue of the magnitude and significance of the Northeast rail situation is addressed through incremental policy adjustments, can it be said that these actions, at least in terms of how they are portrayed, are symbolic, as Murray Edelman would suggest? ? $^{95}$ This issue does not fit well with Edelman's model, in that the masses who are the audience for political symbols are not the focus of attention in this process. Railroads were not regulated for the purpose of protecting general citizen interests, other than in ensuring the availability of the service. Instead, this issue should be seen more as a battle between well-represented interest groups including railroads, shippers, and finan- 


\section{POLICY PERSPECTIVES}

cial institutions. Even expressions of concern provoked by an abandonment were the result of a desire to insure the availability of competition as a means of controlling the pricing of alternate carriers.

It would seem, however, that the largely symbolic elements of this issue surrounded the establishment of Amtrak. Intercity passenger service was used primarily by lower income individuals with no group representation. While Amtrak could be characterized as saving this service for those persons, in fact its creation, at least in part, was for the purpose of enhancing the profitability of the railroads that had been subsidizing it. This view is especially obvious when one considers that the cost to continue operations of those services has long ago exceeded the $\$ 1.9$ billion dollars the federal government received from sale of Conrail.

Although the Northeast rail crisis was a function in part of Penn Central's mismanagement, it also represents a failure on the part of policymakers to heed the warning signs that were before them. Congress had not performed an adequate oversight role with regard to railroad regulation by the ICC. The academic community was interested in railroad industry issues prior to the Penn Central bankruptcy and had foretold these problems. While those warnings had finally reached the Nixon administration, the report that it commissioned arrived just in time to announce what now became obvious to nearly everyone. To its credit, Congress recognized this lack of oversight and in the $3 R$ Act created a system of interagency competition which helped to assure that more than one agency would be involved in considering the solution.

It is interesting to speculate whether the policy solution achieved with regard to the Penn Central bankruptcy and its impact on Northeast rail service could be accomplished in the current political environment. Changes in political philosophies, particularly those evi- dent among more conservative Republicans, seem to have favored limiting the range of tools used by government in addressing economic problems. That philosophical shift might be characterized as preferring more comprehensive solutions to economic problems achieved through monetary policy over the minute tinkering with the private sector which gave rise to Amtrak, Conrail, and the Chrysler loan programs.

Presidents Ford and Carter both favored deregulation of the transportation industry. Early in his administration, Ronald Reagan signaled an unwillingness to continue federal ownership of Conrail. It would be unwise to conclude too quickly that this and subsequent policies relative to federal intervention in the economy signal a radically new era. As tempting as it is to believe that the federal government has chosen a new course that calls for greater trust in Adam Smith's invisible hand, the savings and loan scandal, and the governmental action that it required, are fresh memories.

It is perhaps most prudent to conclude, that serious problems, and particularly those for which few private means for their resolution are apparent, will likely continue to give rise to expressions of public interest by policy makers that will transcend political and economic philosophies in favor of seeking reasonable and effective solutions.

\section{Notes:}

${ }^{1}$ B. Guy Peters, American Public Policy: Promise and Performance, fifth ed. (New York: Chatham House Publishers, 1999).

${ }^{2}$ George W. Hilton, The Northeast Railroad Problem (Washington, DC: American Enterprise for Public Policy Research, 1975) 7.

\footnotetext{
${ }^{3}$ Samuel P. Huntington, "The Marasmus of the ICC: The Commission, the Railroads and the Public Interest," The Yale Law Journal 61 (1952): 467-509.

${ }^{4}$ Henry H. Perritt, Jr., "Ask and Ye Shall Receive: The Legislative Response to the Northeast Rail Crisis," Villanova Law Review 28 (1983): 231-377.
} 


\section{THE CREATION OF CONRAIL}

${ }^{5}$ Theodore E. Keeler, Railroads, Freight and Public Policy (Washington, DC: The Brookings Institute, 1983).

${ }^{6}$ U.S. Department of Transportation, A Prospectus for Change in the Freight Railroad Industry: A Preliminary Report by the Secretary of Transportation (Washington, DC: U.S. Department of Transportation, 1978).

${ }^{7}$ Keeler, 23.

${ }^{8}$ Ibid, 25.

${ }^{9}$ Ibid, 30 .

${ }^{10}$ Saunders, Richard. The Railroad Mergers and the Coming of Conrail. (Westport, CT: Greenwood Press, 1978), 295.

${ }^{11}$ United States Department of Transportation (1978), 60.

${ }^{12}$ Rail Industry Overview 1971, Hearings Before the Subcommittee on Surface Transporation of the Committee on Commerce, U.S. Senate, 92. Congress, $1^{\text {st }}$ session (1971), 4.

${ }^{13}$ Robert E. Bedingfield, "Railway's Route to Failure: Signposts are in Conflict," The New York Times, 6 January 1974, III, 52.

${ }^{14}$ Hilton, 13-14.

${ }^{15}$ Keeler, 26.

${ }^{16}$ Hilton, 15.

${ }^{17}$ Railroad Deregulation Act of 1979: Hearings Before the Subcommittee on Surface Transportation, U.S. Senate, $96^{\text {th }}$ Congress, $1^{\text {st }}$ session (1979), 205.

${ }^{18}$ Hilton, 41.

${ }^{19}$ Ibid, 8.

${ }^{20}$ Keeler, 28.

${ }^{21}$ Frank N. Wilner, "If Only Congress Knew Something About Railroads," Railway Age 197 (1996): 107.

22 Ibid, 154.

${ }^{23}$ Stephen Salsbury, No Way to Run a Railroad: The Untold Story of the Penn Central Crisis. (New York: McGraw-Hill, 1982) 137.

${ }^{24}$ Perritt, 278.

${ }^{25}$ Hilton, 29.

${ }^{26}$ Rail Industry Overview 1971, 5.

${ }^{27}$ Wilner, 164-5.

${ }^{28}$ U, S. Department of Transportation (1978), 139.

${ }^{29}$ Peters, 45 .
${ }^{30}$ Rail Industry Overview 1971, 416.

${ }^{31}$ Salsbury, 209.

${ }^{32}$ Rail Industry Overview 1971.

${ }^{33}$ Ibid, 321.

${ }^{34}$ Wilner, 107.

${ }^{35}$ Saunders, Richard. "Conrail," in Keith L. Bryant (ed.) Railroads in the Age of Regulation, 1900-1980. (New York: Facts on File Publications, 1988), 92-93.

${ }^{36}$ Ibid, 93.

${ }^{37}$ Robbins, 71 .

${ }^{38}$ Saunders, Richard. The Railroad Mergers and the Coming of Conrail. (Westport, CT: Greenwood Press, 1978), 295.

${ }^{39}$ Ibid, 299.

${ }^{40}$ Ibid, 300.

${ }^{41}$ Ibid, 301.

${ }^{42}$ Rail Industry Overview 1971, 49.

${ }^{43}$ Perritt, 296.

${ }^{44}$ Paul W. MacAvoy and John W. Snow, eds., Railroad Revitalization and Regulatory Reform (Washington, DC: American Enterprise Institute for Public Policy Research, 1977).

${ }^{45}$ Ibid, 1.

${ }^{46}$ Robbins, 63 .

${ }^{47}$ Peters, 66

${ }^{48}$ Saunders, Richard. The Railroad Mergers and the Coming of Conrail, (Westport, CT: Greenwood Press, 1978), 307.

49 Joseph Albright, "The Penn Central; A Hell of a Way to Run Government," The New York Times Magazine, 3 November 1974 , $16,96,104$.

${ }^{50}$ Albright, 96.

51 Ibid, 16.

\$2 Ibid, 104.

${ }^{53}$ Ibid, 16.

${ }^{54}$ Saunders, Richard. The Railroad Mergers and the Coming of Conrail. (Westport, CT: Greenwood Press, 1978), 309.

${ }^{55}$ Ibid, 308. 
${ }^{56}$ Hilton, 35.

${ }^{57}$ Keeler, 34 .

${ }^{38}$ Hilton, 35 .

${ }^{49}$ United States Railway Association, Final System Plan for Restructuring Railroads in the Northeast and Midwest Regions Pursuant to the Regional Rail Reorganization Act of 1973 (Washington, DC: U.S. Railway Association. 1975), 3.

${ }^{60}$ Ibid

${ }^{61}$ Perritt, 314.

${ }^{62}$ Ibid, 311.

${ }^{A 3}$ lbid, 304-5.

${ }^{14}$ Saunders, Richard. The Railroad Mergers and the Coming of Conrail. (Westport, CT: Greenwood Press, 1978), 307.

${ }^{65}$ U.S. Department of Transportation (1978), 7.

${ }^{66}$ Peters, $108-117$.

${ }^{67}$ USRA Nomination.

${ }^{68}$ Rail Industry Overview 1971, 21.

${ }^{69}$ Keeler, 98.

${ }^{70}$ Conrail Authorization-Fiscal Year 1979: Hearings Before the Subcommittee on Transportation and Commerce of the Committee on Interstate and Foreign Commerce, U.S. House of Representatives, $9 \mathrm{~S}^{\text {th }}$ Congress, $2^{\text {nd }}$ session (1978).

"John W. Snow and Mark Aron, "Assessment of the Regulatory Reform Sections of the Railroad Revitalization and Regulatory Reform Act," Railroad Revitalization and Regulatory Reform (Washington, DC: American Enterprise Institute for Public Policy Research, 1977), 185.

${ }^{72}$ Railroad Deregulation Act of 1979.250.

${ }^{73}$ Future Funding for Conrail: Hearings before the Subcommittee on Transportation and Commerce of the Committee on Interstate and Foreign Commerce, U.S. House of Representatives, $96^{\text {th }}$ Congress, $2^{\text {mid }}$ session (1980).

${ }^{74}$ William E. Thomas, "Clear Track for Deregulation: American Railroads, 1970-1980," Transportation Law Journal 12 (1982): 207.

${ }^{*}$ Railnoad Deregulation Act of 1979, 199.

76. USRA Nomination, 51.

${ }^{n}$ Winer, 12 .

Ibid
${ }^{74}$ Ibid, 219.

${ }^{* 10}$ Wilner, 219.

"Title VAuthorization Under the Regional Rail Reorganization Act of 1973: Hearings Before the Subcommittee on Transportation and Commerce of the Committee on Interstate and Foreign Commerce, U.S. House of Representatives, $96^{\text {th }}$ Congress, second session (1980), 1-2.

${ }^{2}$ Perritt, 326.

${ }^{83}$ Consolidated Rail Corporation, 12.

${ }^{84}$ Perritt, 333.

${ }^{83}$ Ibid, 340-41.

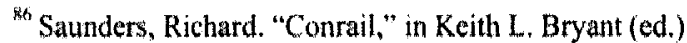
Railroads in the Age of Regulation. 1900-1980. (New York: Facts on File Publications, 1988), 94.

${ }^{87}$ Consolidated Rail Corporation.

Thompson.

${ }^{89}$ Peters, 54.

${ }^{90}$ Perritt. 319.

${ }^{91}$ Charles E. Lindblom, "The Science of Muddling Through" Perspectives on Public Bureaucracy (Cambridge, MA: Winthrop Publishers, 1970), 175-191.

${ }^{92}$ Huntington.

${ }^{3}$ Ibid, 469.

Ibid, 505-06.

${ }^{45}$ Murray Edelman, The Symbolic Uses of Politics (Urbana, IL: University of Illinois Press, 1967).

\section{References:}

Albright, Joseph. "The Penn Central: A Hell of a Way to Run Government." The New York Times Magazine, 3 November 1974.

Bedingfield, Robert E. "Railway's Route to Failure: Sign posts are in Conflict," The New York Times, 6 January 1974.

Conrail Authorization-Fiscal Year 1979: Hearings Before the Subcommittee on Transportation and Commerce of the Committee on Interstate and Foreign Com merce, U.S. House of Representatives, $95^{\text {th }}$ Congress, $2^{\text {nd }}$ session (1978). 


\section{THE CREATION OF CONRAIL}

Edelman, Murray. The Symbolic Uses of Politics. Urbana, IL: University of Illinois Press, 1967.

Future Funding for Conrail: Hearings before the Subcom mittee on Transportation and Commerce of the Committee on Interstate and Foreign Commerce, U.S. House of Representatives, $96^{\text {th }}$ Congress, $2^{\text {nd }}$ session (1980).

Hilton, George W. The Northeast Railroad Problem Wash ington, DC: American Enterprise for Public Policy Research, 1975.

Huntington, Samuel P. "The Marasmus of the ICC: The Commission, the Railroads and the Public Interest" The Yale Law Journal 61 (1952).

Keeler, Theodore E. Railroads, Freight and Public Policy. Washington, DC: The Brookings Institute, 1983.

Lindblom, Charles E., "The Science of Muddling Through." In Fred A. Kramer (ed.), Perspectives on Public Bureaucracy. Cambridge, MA: Winthrop Publishers, 1970.

MacAvoy, Paul W. and Snow, John W. eds., Railroad Revitalization and Regulatory Reform. Washington, DC: American Enterprise Institute for Public Policy Research, 1977.

Perritt, Jr., Henry H., "Ask and Ye Shall Receive: The Legislative Response to the Northeast Rail Crisis." Villanova Law Review 28 (1983).

Peters, B. Guy. American Public Policy: Promise and Performance. Fifth ed. New York: Chatham House Publishers, 1999.

Rail Industry Overview 1971, Hearings Before the Subcommittee on Surface Transporation of the Committee on Commerce, U.S. Senate, 92. Congress, $1^{\text {st }}$ session (1971).

Railroad Deregulation Act of 1979: Hearings Before the Subcommittee on Surface Transportation, U.S. Senate, $96^{\text {th }}$ Congress, $1^{\text {st }}$ session (1979), 205.

Robbins, William. "Brinegar Rail Plan Urges Private, Reduced System." The New York Times 27 March 1973.

Salsbury, Stephen. No Way to Run a Railroad: The Untold Story of the Penn Central Crisis. New York: McGraw-Hill, 1982.
Saunders, Richard. The Railroad Mergers and the Coming of Conrail. Westport, CT: Greenwood Press, 1978.

Saunders, Richard. "Conrail," in Keith L. Bryant (ed.) Railroads in the Age of Regulation, 1900-1980. New York: Facts on File Publications, 1988.

Snow, John W. and Aron, Mark. "Assessment of the Regulatory Reform Sections of the Railroad Revitalization and Regulatory Reform Act." In Paul W. MacAvoy and John W. Snow, eds., Railroad Revitalization and Regulatory Reform. Washington, DC: American Enterprise Institute for Public Policy Research, 1977.

Thomas, William E. "Clear Track for Deregulation: American Railroads, 1970-1980." Transportation Law Journal 12 (1982): 207.

Title $V$ Authorization Under the Regional Rail Reorganiza tion Act of 1973: Hearings Before the Subcommittee on Transportation and Commerce of the Committee on Interstate and Foreign Commerce, U.S. House of Representatives, $96^{\text {th }}$ Congress, second session, 1980.

United States Department of Transportation, A Prospectus for Change in the Freight Railroad Industry: $A$ Preliminary Report by the Secretary of Transporta tion. Washington, DC: U.S. Department of Transportation, 1978.

United States Railway Association. Final System Plan for Restructuring Railroads in the Northeast and Midwest Regions Pursuant to the Regional Rail Reor ganization Act of 1973 Washington, DC: U.S. Railway Association, 1975.

Wilner, Frank N, "If Only Congress Knew Something About Railroads." Railway Age 197, (1996): 107. 